\title{
HUMAN CD46, CD55 AND CD59 EXPRESSION INFLUENCE ON SWINE TRANSGENIC FETAL FIBROBLASTS' SURVIVABILITY IN THE PRESENCE OF HUMAN COMPLEMENT COMPONENTS*
}

\author{
Joanna Zeyland ${ }^{1}$, Daniel Lipiński ${ }^{1,2}$, Ryszard Słomski ${ }^{1,2}$ \\ ${ }^{1}$ Department of Biochemistry and Biotechnology, University of Life Sciences, Wołyńska 35, \\ 60-637 Poznań, Poland \\ ${ }^{2}$ Institute of Human Genetics, Polish Academy of Sciences, Strzeszyńska 32, 60-479 Poznan, Poland
}

\begin{abstract}
Mechanisms regulating the activity of the complement system responsible for the rejection of transplant organs are balanced so that the attack is instantaneous but is restricted to the infected cells of the organism. The most important components regulating its activity comprise CD55 and CD46 factors as well as the CD59 anchored in the cell membrane. Hyperacute response of the immunological system appears to be the key in the xenotransplant rejection and the elaboration of methods preventing its occurrence will give a real chance for the development of xenotransplantation. Gene constructs containing coding sequences of human CD46, CD55 and CD59 were prepared and used to transfect porcine fetal fibroblasts. Stable lines were molecularly characterized for an integration of transgenes by PCR. Lines with a stable integration of transgenes were subjected to further characterization of expression by RT-PCR and vitality test. Molecular characteristics of the transgenic cell lines obtained revealed a steadfast integration and, in the majority of cases, expression of the introduced transgenes. The performed cytotoxicity analysis demonstrated that transgenic lines were characterised by a higher survivability rate than non-transgenic cells in the presence of human serum which proved their protective influence in relation to the activity of the complement system.
\end{abstract}

Key words: CD46, CD55, CD59, complement activation, xenotransplantation

At the present time, cell, tissue and organ transplant therapy provides a real and, frequently, the only treatment method of patients with terminal organ failure, accident victims, suffering from complex immunological deficiencies or tumours of the blood-forming system. The development of transplantology was helped by the introduction of modern techniques of tissue compatibility investigations, improve-

\footnotetext{
* Project no. N R12 003606.
} 
ments in organ sampling and storage methodology, elaboration of immunosuppressive therapy procedures, application of graft rejection diagnostics and monitoring as well as counteracting inflammations. One of the main problems of transplantology is the shortage of transplant organs and that is why attempts are continuously being made to find their alternative sources. Swine appears to be the most suitable donor from among the considered animal species. A considerable phylogenetic distance between the man and swine causes that the xenograft is immediately destroyed as a result of a hyperacute rejection response. This reaction is attributed to the binding of naturally-occurring, pre-formed, xenoreactive antibodies of the recipient to carbohydrate structures present on the surface of the donor cell endothelium leading to the activation of the complement cascade. Among promising strategies of xenotransplant protection is the introduction of genes regulating the complement system activity towards the porcine genome. Mechanisms regulating complement activity are balanced in such a way that, on the one hand, the attack on the surface of pathogens is instantaneous but, on the other hand, it is restricted only to the infected cells in the organism. In the classical pathway, the $\mathrm{C} 1$ protein activation is initiated by the antigen-antibody complex. It does happen, however, that such activation occurs without the participation of immunoglobulins as a result of direct interaction with some bacteria, viruses or C-reactive protein. The complement system, thanks to its capability for spontaneous activation of some constituents, acquired autodestructive properties and its autoactivation is controlled, to a considerable extent, by $\mathrm{C} 1$ inhibitor (Wasowska et al., 2007). The complement is regulated by the family of structurally and functionally similar proteins associated with the cell membrane or occurring in tissue fluids, primarily in the blood plasma.

The most important complement regulators comprise those anchored in cell membranes: the CD55 decay accelerating factor (DAF), CD46 membrane cofactor protein (MCP) and the CD59 membrane inhibitor of reactive lysis (MIRL) factor. DAF inhibits $\mathrm{C} 3$ and $\mathrm{C} 5$ activation by preventing the development of $\mathrm{C} 3$ and $\mathrm{C} 5$ convertases and accelerating their decay. MCP, which is a protein cofactor, controls the release of the $\mathrm{C} 3 \mathrm{~b}$ factor and, therefore, the activity of C3. CD59 prevents the development of the membrane attacking complex which constitutes the final stage of the enzymatic complement cascade. Mature porcine CD59 protein is in $48 \%$ similar to human protein, in $46.5 \%$ to rat protein and in $38 \%$ to the mouse equivalent and, as in the case of human CD59 factor, it is effective in the inhibition of the activity of porcine, human and sheep complement system (Hinchliffe et al., 1998). The DAF factor exhibits the activity which accelerates the breakdown of the complex of convertases and blocks its formation, while the MCP factor constitutes a cofactor for the I factor, hence the above factors act synergistically. Other factors regulating the complement system, such as factor H or CD35, exhibit the activity of both CD46 and CD55 factors. They probably evolved from both of these regulators and embrace their complementary functions (Brodbeck et al., 2000). MCP-DAF soluble hybrid protein, also known as complement activation blocker-2 (CAB-2) exhibits both activities and can successfully block the activity of convertase C3 and C5, both in the classical and alternative activation pathways of the complement system (Higgins et al., 1997). 


\section{Material and methods}

Sequences coding CD46 (1083 bp), CD55 (1155 bp) and CD59 (402 bp) factors used in gene constructs were prepared on the basis of the complete cell RNA. cDNA was synthesised in the reaction of reverse transcription on the complete RNA template employing oligo(dT) starters. cDNA was used as a template in PCR using primers specific for sequences coding individual genes. F starters had additional sequence recognised by the $K p n \mathrm{I}$, while $\mathrm{R}$ starters - by $\mathrm{Xba \textrm {I }}$. Reaction conditions: $94^{\circ} \mathrm{C}-5 \mathrm{~min}$., $94^{\circ} \mathrm{C}-1 \mathrm{~min}$., $56^{\circ} \mathrm{C}-1 \mathrm{~min} ., 72^{\circ} \mathrm{C}-1.30 \mathrm{~min} ., 30$ cycles, $72^{\circ} \mathrm{C}-$ $5 \mathrm{~min}$. PCR products and the vector were hydrolysed by $\mathrm{KpnI}$ and $\mathrm{Xba \textrm {I }}$ at $37^{\circ} \mathrm{C}$ for 2 hours. The hydrolysed inserts were cloned into the pTracer-EF/Bsd A (Invitrogen) vector at $K p n \mathrm{I}$ and $X b a \mathrm{I}$ sites. Ligation products were used to transform competent bacterial cells of $E$. coli XL1-Blue MRF' strain. The correctness of sequences in positive clones was confirmed by cyclic sequencing. Prepared pCD46-GFPBsd, pCD55-GFPBsd and pCD59-GFPBsd plasmids were isolated from bacterial cultures after 12 hour growth at $37^{\circ} \mathrm{C}$ and purified with an UltraMobius 200 (Novagen) kit in order to remove bacterial toxins which could reduce the viability of animal cells. The plasmids were linearised by the ScaI restriction enzyme and later purified on Wizard columns (Promega).

Cell cultures containing porcine fetal fibroblasts of $90-95 \%$ vitality and $30-50 \%$ confluence were transformed with lipofectamine 2000 (Invitrogen). The following types of transfections were performed: with a pCD46-GFPBsd gene construct, pCD55-GFPBsd gene construct and pCD59-GFPBsd gene construct as well as a co-transfection with three constructs. Seventy-two hours after transfer, an 8-day selection was conducted where blasticidine $(5 \mu \mathrm{g} / \mathrm{ml})$ was used as a selection factor. At the termination of the selection process, fibroblast vitality was evaluated and green fluorescent protein (GFP) (reporter marker) expression was checked. Selected, stable lines of porcine fetal fibroblasts exhibiting GFP expression were cultured until obtaining full confluence in order to carry out their molecular characteristics on the basis of the isolated genomic DNA and total RNA.

Cell cultures of full confluence were utilised for genomic DNA isolation using guanidine isothiocyanate (GTC). PCR reaction was conducted using two pairs of starters for each transgene. F starters were placed in the EF-1 $\alpha$ promoter region, whereas $\mathrm{R}$ starters, depending on the construction, either in the region coding CD46 and CD55 or CD59. Starter pairs: EF1-1F and CD46-1R (481 bp) and EF1-2F and CD46-1R (716 bp) were employed to analyse the integration of the pCD46-GFPBsd gene construct. On the other hand, the integration analysis of the pCD55-GFPBsd gene construct was performed using the following pairs: EF1-1F and CD55-1R (393 bp) as well as EF1-1F and CD55-2R (745 bp), whereas EF1-1F and CD59-3R (288 bp) as well as EF1-2F and CD59-3R (511 bp) pairs were employed to analyse the integration of the pCD59-GFPBsd gene construct. The reaction conditions were as follows: $94^{\circ} \mathrm{C}-5 \mathrm{~min} ., 94^{\circ} \mathrm{C}-30 \mathrm{sec} ., 56^{\circ} \mathrm{C}-30 \mathrm{sec}$., $72^{\circ} \mathrm{C}-1 \mathrm{~min}$., 30 cycles, $72^{\circ} \mathrm{C}-5 \mathrm{~min}$. PCR reaction products were fractionated in $1.5 \%$ agarose gel supplemented with ethidium bromide. 
Cell cultures of full confluence were also utilised for total RNA isolation using guanidine isothiocyanate (GTC). cDNA was synthesised and used as a template in the PCR reaction. The authors used: CD46FEx1 and CD46REx1 (519 bp) starters to check the expression of the CD46 factor, CD55FEx1 and CD55REx1 (620 bp) starters for CD55 factor transcripts and the pair of CD59FEx1 and CD59REx1 starters designed to amplify the cDNA gene of $323 \mathrm{bp}$ length - to evaluate the expression of the human CD59 factor controlled by the $E F-1 \alpha$ promoter. In addition, positive control was also employed in the form of PCR reaction on the template of the obtained cDNA with bActF and bActR starters specific for the cDNA $\beta$-actin (300 bp) as well as negative control in the form of PCR reaction on the template of total RNA with bActF0 and bActR0 starters specific for the genomic sequence of $\beta$-actin (445 bp) in order to confirm purity of RNA preparations. The reaction conditions were as follows: $94^{\circ} \mathrm{C}-5 \mathrm{~min} ., 94^{\circ} \mathrm{C}-30 \mathrm{sec} ., 56^{\circ} \mathrm{C}-30$ sec., $72^{\circ} \mathrm{C}-1 \mathrm{~min} ., 30$ cycles, $72^{\circ} \mathrm{C}-$ $5 \mathrm{~min}$. PCR reaction products were fractionated in $1.5 \%$ agarose gel supplemented with ethidium bromide.

Cell cultures of full confluence were detached from the surface by the addition of $750 \mu \mathrm{l} 0.5 \%$ trypsin solution with EDTA and incubation for $5 \mathrm{~min}$. at $37^{\circ} \mathrm{C}$. $200 \mu \mathrm{l}$ of $\mathrm{A}, \mathrm{B} 1, \mathrm{~B} 2, \mathrm{~B} 3, \mathrm{~B} 4$ or $\mathrm{C}$ medium was added to the prepared cell pellets. Medium A: 50\% DMEM, 15\% FBS, 35\% PBS; medium B1: 20\% HS AB, 80\% PBS; medium B2: 30\% HS AB, 70\% PBS; medium B3: 40\% HS AB, 60\% PBS, medium B4: 50\% $\mathrm{HS}$ AB, 50\% PBS, medium C: 50\% thermally inactivated HS AB, 50\% PBS. They were incubated at $37^{\circ} \mathrm{C}$ for $30 \mathrm{~min} .20 \mu \mathrm{l}$ of fibroblast suspension and $\mathrm{A}, \mathrm{B} 1, \mathrm{~B} 2$, B3, B4 or C medium was sampled to which $20 \mu l 0.4 \%$ trypan blue solution was added. This was incubated for $5 \mathrm{~min}$. and then cells were counted under microscope at 10x magnification. Live and dead cells were counted in the Bürker's chamber in accordance with the two side principle in 12 replications. After placing a cover glass on edges close to the grating, a chamber was formed $0.1 \mathrm{~mm}$ deep, $9 \mathrm{~mm}^{2}$ area and $9 \mathrm{~mm}^{3}$ volume. Sums of counted live and dead cells were added obtaining the total amount of cells in $9 \mathrm{~mm}^{3}$ volume. The $\chi^{2}$ two-sided test was used for comparative analyses between the viability of individual transgenic and non-transgenic cell lines as well as between mean survivability of cell lines in relation to the type of the gene construct undergoing expression. The $\chi^{2}$ test was performed with the assistance of the Graphpad Prism 4 (Graphpad Software) computer program.

\section{Results}

The following transfection sets were carried out: pCD46-GFPBsd (8 cell lines), pCD55-GFPBsd (10 cell lines), pCD59-GFPBsd (10 cell lines) and 3-co-transfection ( 8 cell lines). After the termination of the selection process, fibroblast vitality was assessed and the authors also checked whether green fluorescent protein (GFP) (reporter marker) expression took place. The observed GFP expression provided an indirect evidence confirming the integration of the transgene with the genomic DNA as transitional episomal expression of the gene construct in fibroblast cytoplasm can 
also take place. Seven cell lines (Lip30, Lip61, Lip62, Lip63, Lip65, Lip81 and Lip82) failed to survive selection.

Molecular analysis confirmed an integration of each checked transgene for single transfections (pCD46-GFPBsd, pCD55-GFPBsd or pCD59-GFPBsd) as well as for triple set of co-transfection. The RT-PCR analysis of fetal fibroblast lines, in which the integration of the appropriate factors was confirmed, exhibited the presence of CD46, CD55 and CD59 transcripts under the control of the EF-1 $\alpha$ promoter in all analysed lines in the single system confirming stable integration of appropriate transgenes in transcriptionally active sites. RT-PCR analysis of cell lines, with three constructs introduced during co-transfection and confirmed integration of all transgenes, revealed the presence of transcripts of CD46 and CD 59 factors in Lip75, Lip76, Lip77, Lip78, Lip79 and Lip80 lines of porcine fetal fibroblasts and of the CD55 factor in lines Lip75, Lip76, Lip77, Lip78, Lip79 and Lip80.

The following lines were selected for further analyses: non-transgenic lines $2 \mathrm{~B}$, 1B and 5C as well as transgenic lines Lip31 and Lip32 (pCD59-GFPBsd), Lip21, Lip23, Lip24, Lip25 and Lip26 (pCD55-GFPBsd), Lip59 (pCD46-GFPBsd), Lip76, Lip78 and Lip79 (pCD46-GFPBsd, pCD55-GFPBsd, pCD59-GFPBsd). In order to perform the required analyses, cell pellets were suspended in previously prepared media: A, B1, B2, B3, B4 or C. Medium C contained thermally inactivated human blood serum in which complement constituents were not active and provided toxicity control of other compounds present in human serum with regard to the analysed cells. In the performed test, numbers of live and dead cells were added and the percent of live cells was calculated for each replication. During the next stage, mean numbers of live, dead and total cells from 12 replications for individual cell lines were calculated. The performed statistical analysis revealed that there were no significant differences between cell survivability in the $\mathrm{A}$ and $\mathrm{C}$ media for all the examined cell lines, therefore medium A was used as a control. Analyses of the impact of the human serum concentration on the survivability of porcine fetal fibroblasts were carried out by comparing cell survivability of all selected cell lines in individual media. These investigations revealed that the survivability of all the examined nontransgenic cell lines of porcine fetal fibroblasts was the highest in medium A and the lowest in medium B4 containing 50\% human serum. Presence of complement constituents in the human serum reduced non-transgenic cell survivability of cell lines by $61 \%$ in comparison with the control on medium A (Figure 1).

Survivability of all transgenic cell lines of swine fetal fibroblasts, in both the single and triple system, was the highest in medium A and the lowest in medium B4 containing 50\% human serum. The presence of complement constituents in human blood serum reduced the survivability of the transgenic Lip59 cell line with the pCD46-GFPBsd transgene by $13.68 \%$. In the case of the transgenic cell lines containing the pCD55-GFPBsd transgene, cell survivability in the B4 medium, in relation to medium A, decreased by $16.4-29 \%$, while for the cell lines in the triple system - by $6.39-12.26 \%$ (Figure 2 ).

The comparative statistical analysis of survivability inside transgenic cell lines of porcine fetal fibroblasts was carried out for medium B4 using the $\chi^{2}$ test. It revealed statistically significant differences in survivability between seven pairs of cell lines 
containing the pCD55-GFPBsd transgene and absence of such differences for the three examined pairs. Lines with the highest survivability odds ratio were Lip21 and Lip23. No significant differences in survivability were shown between lines Lip31 and Lip32 (pCD59-GFPBsd), whereas within transgenic lines after co-transfection, a statistically significant difference was demonstrated between lines Lip76 and Lip78. Further analyses between individual types of transgenic cells were performed on the following lines: Lip21, Lip23, Lip31, Lip32, Lip76, Lip78 and Lip59. The performed comparative analysis revealed that the transgenic line of porcine fetal fibroblasts Lip76 after co-transfection turned out to be characterised by the highest survivability odds ratio in the presence of $50 \%$ human serum. Depending on the compared pair, line Lip76 was on average characterised by 1.414 to 2.943 higher survivability odds ratio in comparison with the other compared transgenic line in identical conditions. Further analyses revealed that the protective activity of the CD46 factor increased the survivability of transgenic cells in relation to non-transgenic ones by approximately $41.57 \%$, of the CD55 factor - by about $44.82 \%$, of the CD59 factor - by about $38.41 \%$ and all of them together - by $54.56 \%$ for medium B4. The initial mean (medium A) vitality of all transgenic cell lines was almost identical with that of non-transgenic cell lines. Recapitulating, the mean protective impact of factors undergoing expression in the examined cell types increased their survivability by about $44.84 \%$ in medium B4 in relation to non-transgenic cells (Figure 3).

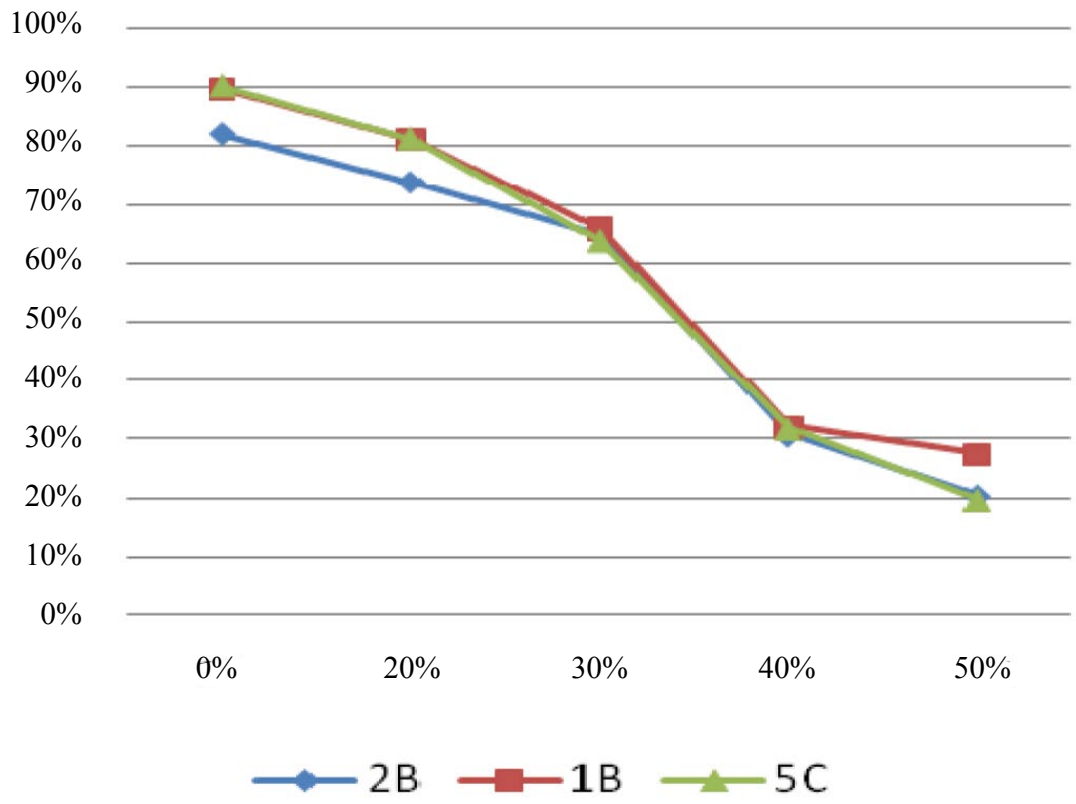

Figure 1. Survivability of non-transgenic cell lines in relation to serum concentration (axis $\mathrm{X}-$ serum concentration, axis $\mathrm{Y}$ - survivability in \%) 


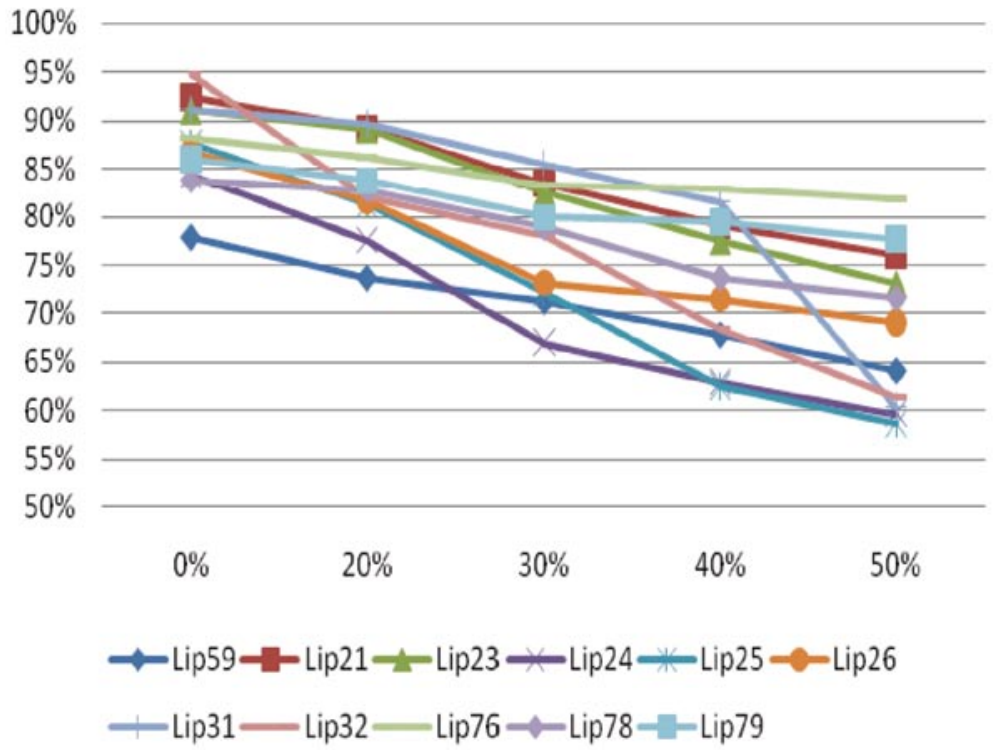

Figure 2. Survivability of transgenic cell lines in relation to serum concentration (axis $\mathrm{X}-$ serum concentration, axis $\mathrm{Y}$ - survivability in \%)

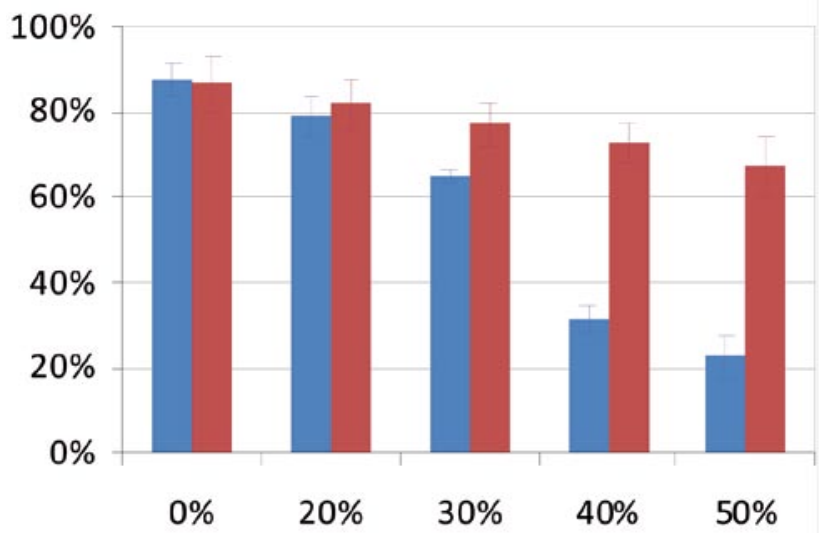

Figure 3. Mean survivability values of non-transgenic (blue colour) and all transgenic cell lines (red colour) together with standard error (axis $\mathrm{X}$ - serum concentration, axis $\mathrm{Y}$ - survivability in \%)

\section{Discussion}

The use of pigs as donors is restricted by the immunological barrier resulting from the presence of natural xenoreactive antibodies as well as the activation of 
the complement system (Bennet et al., 2000). The possibility of elimination of the hyperacute rejection by genetic modifications limiting the activity of antibodies encouraged scientists to seek strategies aiming at humanisation of animal organs by ensuring the expression of genes which act as regulators of the human complement. Coexistence of genetic modifications ensuring expression, their possibly largest numbers as well as modifications altering the distribution of carbohydrates on the surface of swine cells will most probably result in quantitative and qualitative restriction of the pharmacological treatment which weakens the immunological system by blocking its functions. Using the microinjection method, the prepared gene constructs will be introduced into pronuclei of fertilised swine oocytes with the aim to obtain transgenic animals. However, it may turn out that costs associated with the number of performed experiments and maintenance of a huge number of animals, only potentially transgenic, in which the presence and, even more so, the expression of the transgene have not been confirmed, will be too high. Therefore, experiments on transgenic cells are an essential, intermediate stage leading to obtaining animals for the needs of xenotransplantation and have, as their target, the preparation of lines of stable integration and high transgene expression. Selected monotransgenic lines can be used for somatic cloning with the aim to obtain genetically modified animals and, later, their crossing. Only polytransgenic animals with numerous modifications which have been obtained by crossing or co-transfection by several gene constructs will become a unique storehouse of organs for medical purposes (Liu et al., 2008). CD46, CD55 and CD59 fulfil different functions and are active on several levels of the cascade of the complement activation process. Majority of cells found in the human body synthesise at least two of the above-mentioned factors and their action is synergistic, less frequently, additive. First experiments in which attempts were made to correlate several strategies preventing transplant rejection were carried out on mice models. Co-expression of the human $\mathrm{H}$ transferase and the CD59 factor in the splenocytes of transgenic mice increased the resistance of these cells to the action of human serum in comparison with the non-transgenic control (Costa et al., 1999). Similarly, in the case of the expression of the CD59 factor in splenocytes of mice with inactivated gene of $\alpha 1,3$-galactosylotransferase, cell survivability was higher in comparison with the control and adequate to the survivability of splenocytes exhibiting $\mathrm{H}$ transferase and CD59 factor co-expression (Tango et al., 1997). The performed experiments prove that complex strategies of organ protection are far more effective than simple modifications and the impact of their action is frequently additive. However, the performed analysis of the results obtained on porcine fetal fibroblasts failed to show simple protective additiveness of the influence of individual CD46, CD55 and CD59 regulators in lines exhibiting their co-expression, although synergistic effect of these factors was observed. Despite the absence of additiveness of the activity of individual proteins, lines employing the triple system were characterised by the highest survivability and resistance to complement-mediated cell lysis. Similar results were reported for swine aortal endothelial cells transfected by three adenoviral vectors containing, respectively, sequences of CD46, CD55 and CD59 factors (Nagahama et al., 2002). The CD59 factor becomes active at the final stage of the response formation of the complement system, whereas CD46 and CD55 act at the 
same level by way of preventing C3 and C5 convertase formation, which explains the additiveness of the activity of these regulators. Experiments carried out on xenoendothelial cells following transfection by CD46, CD55 and CD59 factors proved that cells exhibiting the expression of individual factors in a two-component system (CD46 and CD55 or CD55 and CD59) were characterised by higher survivability than lines with the expression of only one of them but their activities sum up.

In addition, it was demonstrated that the protective action of CD55 and CD59 factors undergoing co-expression was higher than that of CD55 and CD46 (Huang et al., 2001). Small differences between data obtained by various research teams could have been preconditioned multifactorially and may have resulted from the number and method of the performed analyses, animal species and the test employed for statistical analysis. Moreover, the type of the gene construct introduced into the animal cell transgenes is of paramount importance if high level of expression is expected (Recillas-Targa, 2006). It is not very uncommon for gene constructs containing cDNA to undergo expression at a lower level than those in which genome sequences were placed. Within cDNA, the so called cryptic excision sites can be found which exhibit similarity with regards to motifs of the highest compatibility for the appropriate excision sites which interact with donor sequences situated within the intron (Pertea et al., 2001). Absence of these interactions may lead to the loss of part of the exon. Within their sequence, some introns contain interior enhancing elements and their removal causes a dramatic decline in the level of transgene expression. The presence of introns also stabilises mRNA in the nucleus and assists transcript transport to cytoplasm. On the other hand, the introduction of huge genome sequences into gene constructs can be limited by the capacity of the vector and entails risks of the DNA degradation during the process of microinjection. Plasmid vectors together with the incorporated DNA fragment usually do not exceed the length of fifteen thousand base pairs because the transformation efficiency is negatively correlated with the size of insert. The expression level of cDNA containing gene constructs depends on the number of incorporated copies, whereas in the case of genome sequences, no such correlation was observed. Too small or too large number of incorporated copies may lead to excessively low expression or to methylation and heterochromatinisation causing transgene silencing (Lipiński et al., 2006). Long DNA fragments, on the other hand, change significantly the site structure into which they build themselves in and may disturb its stability leading to its transformation into a transcriptionally inactive site (Zhou et al., 2005). The preparation of three different gene constructs containing cDNA of CD46, CD55 and CD59 factors was, therefore, enforced by technical difficulties associated with obtaining polycistronic constructs and the risk that sequences situated further away from the promoter could have a lower level of expression. The authors adopted lipofection as the method of DNA introduction into cells (Michalak et al., 2004; Lipiński et al., 2007) and this choice was based on the experience of a research team indicating that this procedure is easy, effective and allows transfection of various cell types without limiting the length of the introduced DNA (Oliveira et al., 2005). Gene constructs situated inside liposomes exhibit stability and are protected against the activity of nucleolytic enzymes. Positively charged complexes, developed as a result of mutual 
interactions of lipids and DNA, penetrate into the cell by way of endocytosis. The total of 36 porcine fetal fibroblasts were subjected to lipofection obtaining 29 lines in which the integration of the introduced DNA was confirmed. The efficiency of the employed method amounted to $80 \%$ confirming that lipofection is an exceptionally simple and effective method of cell transfection. Control over hyperacute and acute rejection processes induced by the immunological system with respect to organs derived from animals will allow extending the lives of patients waiting for a transplant. Unfortunately, so far it has been impossible to determine the level of risk associated with the transfer of animal pathogens during the functioning of the xenograft in the human organism (Wilson, 2008). At the present time, xenozoonoses constitute one of the main arguments blocking initiation of clinical trials. Only sterile rearing of animals (in the case of xenotransplantation - pigs) in conditions of continuous isolation and monitoring of individual animals and pathogen diagnostics will make it possible to limit possibilities of exposing patients to additional stress and danger (Bucher et al., 2005). Retroviruses, which in natural living conditions do not pose any serious threat for humans, appear to cause most problems in control and monitoring. Unfortunately, as a result of the application of dramatic immunosuppression, xenotransplants may provide a source of very virulent virions in human organisms. Provided that obstacles of immunological, microbiological and physiological nature are successfully overcome, xenotransplantation will become a powerful tool of modern medicine saving human health and life. That is why it is important to secure ethical, social and financial support for medical research projects aimed at obtaining and rearing genetically modified animals.

\section{References}

Bennet W., Sundberg B., Lundgren T., Tibell A., Groth C.G., Richards A., White D.J., Elgue G., Lars son R., Nils s on B., Korsgren O. (2000). Damage to porcine islets of Langerhans after exposure to human blood in vitro, or after intraportal transplantation to cynomologus monkeys: protective effects of sCR1 and heparin. Transplantation, 69: 711-719.

Brodbeck W.G., Kuttner-Kond o L., Mold C., Medof M.E. (2000). Structure/function studies of human decay-accelerating factor. Immunology, 101: 104-111.

B u c h e r P., M or el P., B u h l e r L.H. (2005). Xenotransplantation: an update on recent progress and future perspectives. Transpl. Int., 18: 894-901.

Cost a C., Zh a o L., D e ces a re S., F od or W.L. (1999). Comparative analysis of three genetic modifications designed to inhibit human serum-mediated cytolysis. Xenotransplantation, 6: 6-16.

H i g g in s P.J., K o J.L., L o b e 11 R., S a r d o n in i C., A l e s s i M.K., Y e h C.G. (1997). A soluble chimeric complement inhibitory protein that possesses both decay-accelerating and factor I cofactor activities. J. Immunol., 158: 2872-2881.

Hinchliffe S.J., Rushmere N.K., Hanna S.M., Morgan B.P. (1998). Molecular cloning and functional characterization of the pig analogue of CD59: relevance to xenotransplantation. J. Immunol., 160: 3924-3932.

Huang J., Gou D., Zhen C., Jiang D., Ma o X., Li W., Chen S., Ca i C. (2001). Protection of xenogeneic cells from human complement-mediated lysis by the expression of human DAF, CD59 and MCP. FEMS Immunol. Med. Microbiol., 31: 203-209.

Lipiński D., Duszewska A.M., Zeyland J., Mały E., Gawron W., Rynkowska A., Rek lewski Z., Sło mski R. (2007). Obtaining transgenic bovine skin fibroblasts containing human interferon alpha. Anim. Sci. Pap. Rep., 25: 211-220. 
Lipiński D., Michalak E., Słomski R. (2006). DNA integration in animal transgenesis (in Polish). Med. Weter., 62: 992-997.

Li u B., Cheng C., Wu Y., W e i J., Li G., Ma T. (2008). Transgenic mice designed to express human alpha-1,2-fucosyltransferase in combination of human DAF and CD59 to avoid xenograft rejection. Sci. China Ser. C, 51: 199-204.

Michalak E., Kątska-Książkiewicz L., Kalak R., Lipiński D., Wielgus K., J a rmuż M., Szal at a M., R yń sk a B., S mor ąg Z., Słomski R. (2004). In vitro transfection of fibroblasts and evaluation of transgenesis in long-term cell cultures. Ann. Anim. Sci., 4: 233-240.

Nag a hama M., Shira ishi M., O shiro T., Taira K., Sugawa H., Nozato E., Nomur a H., N a g a min e M., Muto Y. (2002). Adenovirus-mediated gene transfer of triple human complement regulating proteins (DAF, MCP and CD59) in the xenogeneic porcine-to-human transplantation model. Part I: in vitro assays using porcine aortic endothelial cells. Transpl. Int., 15: 205-211.

Olive ir a R.R., Carvalho D.M., Lis a uskas S., Mello E., Vianna G.R., Dode M.A., R u m p f R., A r a g a F.J., R e ch E.L. (2005). Effectiveness of liposomes to transfect livestock fibroblasts. Genet. Mol. Res., 4: 185-196.

P e r te a M., Li in X., S a l zberg S.L. (2001). GeneSplicer: a new computational method for splice site prediction. Nucleic Acids Res., 29: 1185-1190.

R e c i ll a s - T a r g a F. (2006). Multiple strategies for gene transfer, expression, knockdown, and chromatin influence in mammalian cell lines and transgenic animals. Mol. Biotechnol., 34: 337-354.

Tango M.J., Safaris E., Romanella M., Aminian A., Katerelos M., Somerwille C., T e arle R.G., P e ar s e M.J., D' A p i c e A.J.E. (1997). Additive effects of CD59 expression in Gal knockout mice in vitro but not in an ex vivo model. Xenotransplantation, 4: 25-33.

W a s ow ska B.A., L e e C.Y., H a lu sh ka M.K., B aldw in W.M. 3rd. (2007). New concepts of complement in allorecognition and graft rejection. Cell Immunol., 248: 18-30.

Wils o n C.A. (2008). Porcine endogenous retroviruses and xenotransplantation. Cell Mol. Life Sci. 65: 3399-3341.

Zhou C.Y., McInnes E., Copeman L., Langford G., Parsons N., Lancaster R., Richards A., Carrington C., Thompson S. (2005). Transgenic pigs expressing human CD59, in combination with human membrane cofactor protein and human decay-accelerating factor. Xenotransplantation, 12: 142-148.

Accepted for printing 27 IV 2012

\title{
JOANNA ZEYLAND, DANIEL LIPIŃSKI, RYSZARD SŁOMSKI
}

\section{Wpływ ekspresji CD46, CD55 oraz CD59 czlowieka na przeżywalność transgenicznych fibroblastów płodowych świni w obecności składników dopełniacza czlowieka}

\author{
STRESZCZENIE
}

Ksenotransplantacja w układzie zwierzę-człowiek może przyczynić się do rozwiązania podstawowego problemu transplantologii, którym jest niedobór narządów do przeszczepów. Techniki inżynierii genetycznej stworzyły możliwość wyprodukowania genetycznie zmodyfikowanych świń, których narządy mogłyby utrzymać przy życiu pacjentów. Czynnikiem kluczowym odrzucania ksenoprzeszczepu wydaje się być nadostra reakcja układu immunologicznego, a opracowanie metod zapobiegania jej wystąpienia da realne szanse na rozwój ksenotransplantacji. Mechanizmy regulujące aktywność układu dopełniacza, odpowiedzialnego za odrzut narządów przeszczepionych są zrównoważone, by atak był natychmiastowy, ale ograniczył się do zainfekowanych komórek organizmu. Najważniejszymi składnikami regulującymi aktywność układu dopełniacza są zakotwiczone w błonie komórkowej czynniki CD55 
oraz CD46, a także czynnik CD59. Przygotowano konstrukcje genowe zawierające odpowiednio sekwencje kodujące czynników CD46, CD55 i CD59 człowieka pod kontrolą promotora EF-1 $\alpha$, którymi transfekowano metodą lipofekcji fibroblasty płodowe świni. Molekularna charakterystyka wyprowadzonych transgenicznych linii komórkowych wykazała stabilną integrację oraz u większości ekspresję wprowadzonych transgenów. Analiza cytotoksyczna wykazała, że linie transgeniczne charakteryzują się wyższą przeżywalnością niż komórki nietransgeniczne w obecności surowicy człowieka, co dowodzi ich ochronnego wpływu w stosunku do aktywności układu dopełniacza. Uzyskane stabilne linie komórkowe, zwłaszcza te z wysokim działaniem ochronnym w stosunku do układu dopełniacza, można w przyszłości wykorzystać do uzyskania transgenicznych zwierząt na drodze klonowania somatycznego. 